\title{
THE EFFECTIVENESS OF USING MICROSOFT TEAMS IN STUDENTS' SPEAKING PERFORMANCE DURING PANDEMIC COVID-19 OUTBREAK
}

\author{
Author \\ Kazue Salzabella Rachelinda, Khoirul Anwar, Ulfatul Ma'rifah \\ Universitas Muhammadiyah Gresik \\ Ask.kazueofficial@gmail.com
}

\begin{abstract}
The spread of Covid-19 changed the world to deal with the transformation of learning platform from the traditional classroom to virtual classroom. Due to this situation, the educational instructors or teachers are be able to find and use the appropriate online learning platform like Zoom, Google Classroom, Gmeet, Microsoft Teams, etc, to support the interaction between teacher and students particularly on speaking class. The aim of this study is to investigate the effect of Microsoft Teams in supporting students' speaking performance for English Department students. This study is quantitative reasearch with quasi experimental design. The subjects in this study are the second semester of English Department from University of Muhammadiyah Gresik which consist of 18 students each group for experimental and control group. The result of the finding revealed that Microsoft Teams was effective for supporting the interaction between teacher and students by provide the complete features and significantly support the improvement of students' speaking performance; Pronunciation (13.85\%), Grammar (9.37\%), Vocabulary (8.95\%), Fluency (10.76\%) and Comprehension (5.79\%). Therefore, this study not only helps the researchers in the use of Microsoft Teams as the online learning platform for University level but also leads to provide analysis in another aspect of english skills (Reading, Listening and Writing).
\end{abstract}

Keywords: Speaking Performance, Media Interaction, Microsoft Teams.

\section{INTRODUCTION}

Speaking for some Indonesian students still widely discussed as a problem in mastering English language. Even more, the implementation of speaking itself frequently done in a traditional learning which is teacher and students meet in the classroom. But, the spread of Covid-19 outbreak changed the world to deal with this pandemic which has inflicted almost all sectors of human activities, including education. This pandemic has created educational interruption and drastically altered the lifestyles of the whole world with billions of people being obliged to "work and learn from home". It was more disconcerting to know that reports indicated a daily increase in the number of new cases and mortality from Covid-19. As at January, 2021, the number of Covid-19 cases in Indonesia has exceed one million cases and 
more than 29 thousand deaths. In this situation, all types of educational program switched from "face to face" to the online learning. Teacher still found the problem of mastering english speaking in traditional classroom [1], it will have another complicated problem appear when do it in an online classroom [2].

Several problems arised because of speaking is not an easy skill to be mastered. It also bring challenges for some Indonesian students, particularly on how to speak english fluently on learning english process in every situation such as pandemic. In direct communication they do not have more time to think what they will to speak and it usually happen spontaneously without preparing. Besides that, in speaking we can not revise or edit our speaking such as in writing or reading skills. Even most of the university students are powerless to speak English well while they have learned the language for at least four years. The reason why speaking is harder in an online class because speaking happen spontaneously while people do not have any preparation for developing the topic [3]. Also can be caused by internal and external factors, the internal factors such as fear of making mistakes and sheepishness when speak out [4].

Whereas, the external factors such as have a limited opportunity to accomplish English both inside and outside classrooms. Another research by have found the problem in teaching speaking during online class are caused by some factors originating from performance conditions (prepareness, time limit, setting up, performance standards and amount of support), affective factors (self-confidence, motivation, perception, discomfort/anxiety and feedback during speaking activities), aspect of speaking (pronounciation, grammar, fluency, comprehension and vocabulary) and also the technology that supported the process of teachinglearning [5]. Technology innovation should be implemented on virtual class, The problem in an online class can be appeared when the technology itself not available for supporting the interaction of teacher and students. After knowing the problem during online class, teacher should find the appropriate way and media interaction (technology) for supporting speaking performance as an interaction between teacher and students in online class. There are lots of online media that can facilitate student and teacher in online class, such as Zoom, Google Classroom, Gmeet, Microsoft Teams, etc.

Based on some media that have been mentioned above, the problem is on the media that should be supported with the criteria of speaking class, those are provide visual (video), audio, text and assessment form. The previous research, Microsoft Teams claimed as very good media that have those criterias. But, the large portion of using Microsoft Teams are conducted on another subject. So, in this case, researcher is interested to conduct this study to investigate the effectiveness of using Microsoft Teams in students' speaking performance for English Department students. 


\section{METHODS}

The approach in this study uses quasi experimental research design, namely to predict the cause and effect of the relationship between variable of dependent and independent. The purpose of this study is to examine the effect of Microsoft Teams on students' speaking performance. In this study, there are two variables. They are speaking performance as dependent variable and Microsoft Teams as independent variable. There will be two groups. Those are experimental group which will be given the treatment by the teacher strategy that is "Speaking Performance using Microsoft Teams" and control group which will be given a treatment with "Speaking Performance using Video Recording". The researcher gives pre-test and post-test to collect the data in order to find out the result between the student of experimental group and control group also to see the effect of using Microsoft Teams in students' speaking performance during pandemic Covid-19 Outbreak.

In this research, the subject is the second semester of English Department at University of Muhammadiyah Gresik. There are 36 students will be divided into two groups, one is experimental group and the other is control group. The researcher choose this population because the students at the second semester were expected to have adequate speaking basic in university level. The sampling technique of this study is simple random sampling, which is choosing a subset of participants from a population randomly.

The researcher uses procedure to collect the data : the first step is the researcher divides the subject into two groups (experimental and control group). The second step is the researcher makes speaking test for pre-test and post-test which consist of performing speech. The third step is gives the treatment "Speaking Performance using Microsoft Teams" toward experimental group and "Speaking Performance using Video Recording" for control group. After the treatment, the researcher gives the post test for experimental and control group. Then, for analyzing the data, the researcher will use SPSS to compare the data. After that do interview for experimental group about the advantages and disadvantages of using Microsoft Teams. The form of the test is an oral test (speech), and the rubric for measuring the test is gained from scoring guide by David Harris (1969) includes scoring for Pronounciation, Grammar, Vocabulary, Fluency and Comprehension (Aspect of Speaking Performance) [1].

\section{DISCUSSION}

The result of this research is to get the answer of research goal namely; how the effect of Microsoft Teams on students' speaking performance during online class in pandemic situation. The following are the result that the researchers got from test and interview as the answer of these aims :

a. The Score Level of Pre Test and Post Test 
Table 1 : Score of Pre-Test

\begin{tabular}{|c|c|c|c|c|c|c|}
\hline \multirow{2}{*}{ Score } & \multicolumn{3}{|c|}{ Experimental Group } & \multicolumn{3}{c|}{ Control Group } \\
\cline { 2 - 5 } & Freq & F(\%) & Mean & Freq & F(\%) & Mean \\
\hline$<70$ & 10 & 55.56 & 69.2 & 16 & 88.89 & 62.5 \\
\hline $70-100$ & 8 & 44.44 & & 2 & 11.11 & \\
\cline { 6 - 7 } & & & & & \\
\hline
\end{tabular}

Table 2 : Score of Post-Test

\begin{tabular}{|c|c|c|c|c|c|c|}
\hline \multirow{2}{*}{ Score } & \multicolumn{3}{|c|}{ Experimental Group } & \multicolumn{3}{c|}{ Control Group } \\
\cline { 2 - 6 } & Freq & F(\%) & Mean & Freq & F(\%) & Mean \\
\hline$<70$ & - & 0 & 75.9 & 10 & 55.56 & 68.4 \\
\hline $70-100$ & 18 & 100 & & 8 & 44.44 & \\
& & & & & & \\
\hline
\end{tabular}

Based on the table above, The number of students who got lower score in experimental class was 10 students (55.56\%) with the lowest score was 60 and the higher score was 8 students (44.44\%) with the highest score was 78. While, in the control class, the number of students who got lower score was 16 students $(88.89 \%)$ with the lowest score was 56 and the higher score was 2 students $(11.11 \%)$ with the highest score was 70 . Furthermore, the table above also showed the mean of pre-test in experimental class was 69.2 and control class was 62.5. In other side, the lowest score of students in experimental class was 70 and the number students who got the higher score was 18 students $(100 \%)$ with the highest score was 89 . While, in the control class, the number of students who got lower score was 10 students $(55.56 \%)$ with the lowest score was 60 and the higher score was 8 students $(44.44 \%)$ with the highest score was 78 . The table above also showed the mean of pre-test in experimental class was 75.9 and control class was 68.4. Hence, the mean score of post test is higher than the pre-test, which there is improvement on students score.

b. The Improvement of Students' Speaking Performance

Table 3 : The Improvement of Students' Speaking Performance

\begin{tabular}{|c|c|c|c|}
\hline \multirow{2}{*}{ Indicators } & \multicolumn{2}{|c|}{ Mean Score } & Improvement \\
\cline { 2 - 3 } & Pre-Test & Post-Test & \\
\hline Pronounciation (P) & 65 & 74 & 13.85 \\
\hline
\end{tabular}




\begin{tabular}{|c|c|c|c|}
\hline Grammar $(\mathrm{G})$ & 64 & 70 & 9.37 \\
\hline Vocabulary $(\mathrm{V})$ & 67 & 73 & 8.95 \\
\hline Fluency $(\mathrm{F})$ & 65 & 72 & 10.76 \\
\hline Comprehension $(\mathrm{C})$ & 69 & 73 & 5.79 \\
\hline Total & 330 & 362 & 9.69 \\
\hline Average & $\mathbf{6 6}$ & $\mathbf{7 2}$ & $\mathbf{9 . 0 9}$ \\
\hline
\end{tabular}

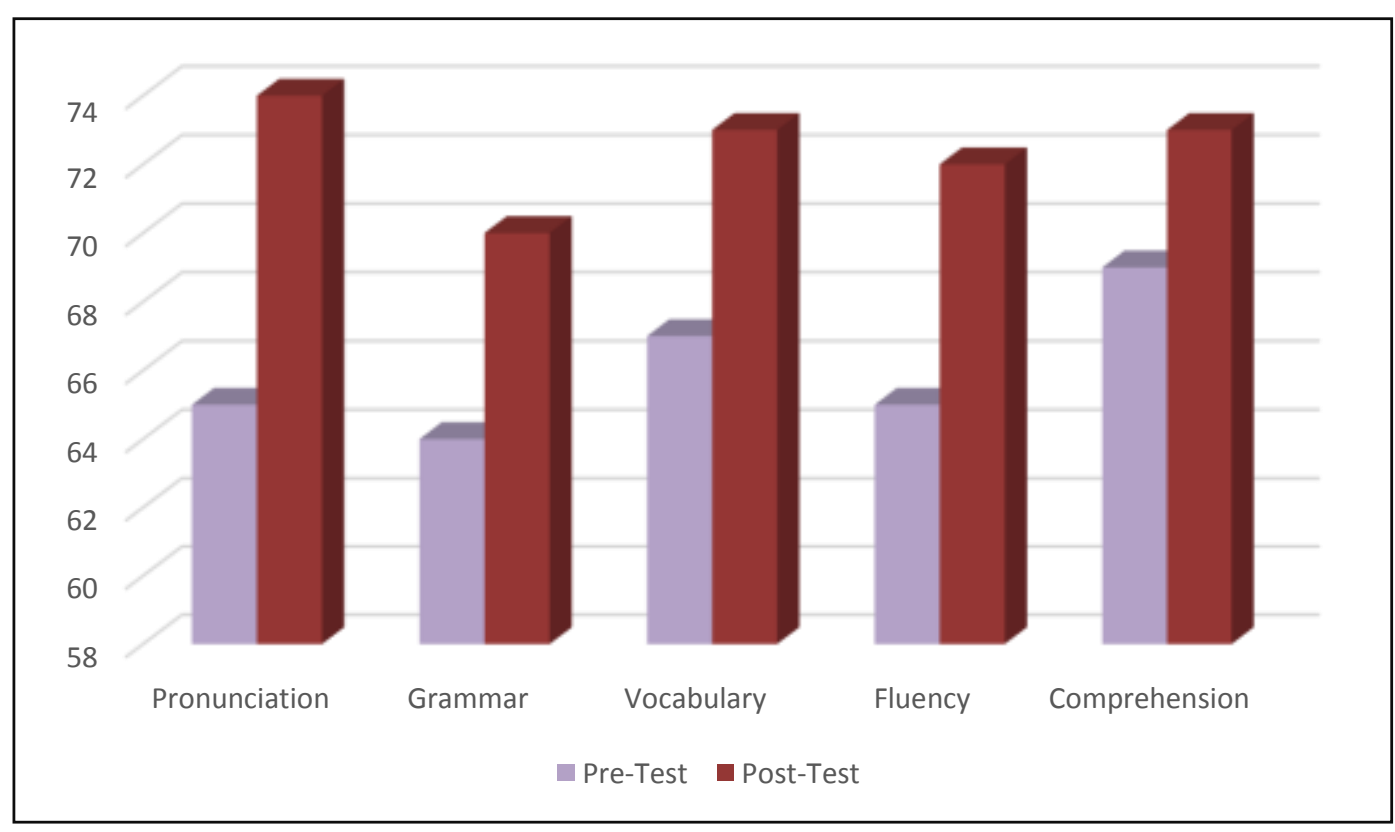

proved $(9.09 \%)$ from the mean 66 in the pre-test and 72 in the post test. From five indicators of speaking performance, the students' score in a pronunciation was improved (13.85\%), Grammar was improved (9.37\%), Vocabulary was improved (8.95\%), Fluency was improved (10.76\%) and Comprehension was also improved (5.79\%). Based on these result, it can be conclude that the use of Microsoft Teams was affective in improving students' speaking performance through speech.

c. Students Interview Result

Based on the Interview result, almost all of the students found that Microsoft Teams is better than other media to use it in online speaking class because provide many features such as sharing content or video, having a form of assigment, giving the feedback, providing better storage. In other side $84 \%$ students told that this application consuming too much data, $8 \%$ explained this application can not record the meeting using the Web version, and others explained that they did not found the disadvantages of this application. 


\section{CONCLUSION}

Based on the finding and the discussion, the researcher concludes that Microsoft Teams was effective to support students' speaking performance in online speaking class during pandemic Covid-19. It was proven by the students' mean score in post-test was greater than in pre-test $(72>66)$. The score of students' speaking performance was improved $9.09 \%$ from the mean 66 in the pre-test and 72 in the post test. From five indicators of speaking performance, the students' score in a pronunciation was improved (13.85\%), Grammar was improved (9.37\%), Vocabulary was improved (8.95\%), Fluency was improved $(10.76 \%)$ and Comprehension was also improved (5.79\%). It can be concluded that the use of Microsoft Teams was affective in improving students' speaking performance in online speaking class through speech. Based on hyphothesis testing, the null hypothesis $\left(\mathrm{H}_{0}\right)$ was rejected whereas the alternative hypothesis $\left(\mathrm{H}_{1}\right)$ was accepted. It was proven by the Sig. (2-tailed) showed 0.000 $<0.05$. It means that there was significant effect of using Microsoft Teams in students' speaking performance.

This research contributes to the knowlegde of teachers, readers and other researchers in the use of Microsoft Teams as a media that support online learning. There are complete featres to facilitate interaction between teacher and students. Presentations can also be done optimally, having interaction like the actual class. This can also minimize the use of learning media that is too much for one subject. Other researcher can also develop and investigate another aspect of speaking in detail using Microsoft Teams. This media is properly used to be developed for the virtual teaching english speaking process.

Teaching English speaking in the situation such as pandemic Covid-19 that changed the way of teaching from offline to the online does not depend on the program only but more important is how the teacher presents the lesson and uses various media to manage the online speaking appropriately. Based on the conclusion above, the researcher proposes the following suggestions: 1) For the teacher should be more creative to enrich their teaching media and material. Due to pandemic situation, teacher have to facilitate students to be independent in online learning. Teaching using very complete application that served video visual, audio, text, form of assigment is an effective way in this situation especially on teaching speaking. That's the reason why it is suggested for the teacher to use Microsoft Teams in online teachinglearning, because this media is completed and served video visual, audio, text, form of assigment. 2) For the students are hoped to be more active in the class and creative in developing their ideas in do a speaking. They have to comprehend the general concept of the main material clearly before do a speaking. 3) For the next researcher, the result of this research can be used as reference and can be applied this media in the other english skill (listening, reading or writing) when teaching english in the online class. Or can be applied in another subject when teaching 
english material in online class.

\section{REFERENCES}

Agung, M \& Ofianto. (2021). Penggunaan Microsoft Teams Dalam Pembelajaran Daring pada Mata Pelajaran Sejarah di SMA Negeri 1 Bukittinggi. Jurnal Kronologi. 3(1)

Arifin, Imam. (2017). Improving The Students' Speaking Skill Through Group Investigation Technique Of The Seventh Grade Students Of Mts Sudirman Jambu Semarang In The Academic Year 2016/2017.

Ariyanti, A., \& Mahakam, W. G. (2016). Psychological Factors Affecting EFL Students' Speaking Performance.

Astuty, R. R. (2013). The Factors Affecting Students' Motivation In Participating Speaking Activity In Speaking For Particular Purposes Class English Education Study Program Teacher Training And Education Faculty Participating Speaking Activity In Speaking For.

Ayu, D., Wiryadi, A., Ayu, P., \& Dharmayanti, P. (2016). Pengaruh anxiety dalam Speaking Activities.

Baidawi, A. (2016). Using Visual Media In Teaching Speaking. Okara Journal Of Languages And Literature, 1(1), 54-65.

Brown, H. D. (2004). Language Assessment : Principle And Classroom Practices. New York : Longman, Pearson Education

David Harris. (1969). Testing English As A Second Language. New York, McGraw-Hill.

Divyapriya. (2020). Assessing the effectiveness Of Using Microsoft Teams During Covid-19 For Online Learning : A Students' Perspective.

Dompas, B. (2021). Analisis Penerimaan Microsoft Teams Sebagai Sarana Pembelajaran Daring Bagi Mahasiswa di Universitas Atma Jaya Yogyakarta.

Ermawati, N. (2020). The Analysis Of Students' Perceptions On The Efficient Applications Used In Online Learning In The Midst Of Covid-19 Pandemic (A Survey At The Fifth Semester Students Of English Education Department Of Iain Salatiga).

Gebi, M. (2017). An Analysis on Students' Anxiety Factors In Speaking Test an Analysis on Students' Anxiety Factors In Speaking Test.

Guzacheva, N. (2020). Zoom Technology As An Effective Tool For Distance Learning In Teaching English to Medical Students. Bulletin of Science and Practice, 6(5), 457-460.

Halgin, Richard P. \& Kraus, S. (2007). Abnormal Psychology. New York: McGraw-Hill.

Harris, David P. (1969). Testing English as a Second Language. McGraw-Hill.

Harmer. (2001). The Practice of English Language Teaching, Cambridge: Longman.

Hubbard \& Balley. (2018). Mastering Microsoft Teams. Mastering Microsoft Teams.

Jannah, W., \& Hartono, R. (2018). Students' Speaking Assessment Used by English Teachers Based on the 2013 Curriculum. 8(01), 359-369.

Koran, S. (2015). The Role of Teachers in Developing Learners Speaking Skill. 6th International Visible Conference on Educational Studies and Applied Linguistics, 400-416.

Leong, L.-M., \& Ahmadi, S. M. (2017). An Analysis of Factors Influencing Learners' English-Speaking Skill. International Journal of Research in English Education, 2(1), 34-41.

Leu, E. (2005). The Role of Teachers, Schools and Communities in Quality Education : A Review of The Literature. AED Global Learning Group.

Maher, A., \& Al, M. (2016). Problems and Difficulties of Speaking That Encounter English Language Students at Al Quds Open University. 5(12), 96-101.

Minghe, G., \& Yuan, W. (2013). Affective Factors in oral English Teaching and Learning. Higher Education of Social Science. 5(3), 57-61.

Mohammed, A. H. (2015). Improving Iraqi Secondary Students' Speaking Performance through 


\section{UMGCINMATIC : $1^{\text {st }}$ Rethinking Education during Covid-19 Era: Challange and Innovation}

Volume 1 No 2

Problem. 3(12), 87-96.

Neken, Ariani \& Haryanto, D. (2010). Pembelajara Multimedia di Sekolah. Jakarta: Prestasi Pustaka.

Nguyen, Tuan. (2015). The Effectiveness of Online Learning: Beyond No Significant Difference and Future Horizons. MERLOT Journal of Online Learning and Teaching. 11(2) : 309-319.

Nunan, D. (2003). Practical English Language Teaching, New York: The McGrawHillCompanies, Inc

Nurazizah, H., Youlia, L., \& Ruby, B. (2019). WhatsApp Voice Note in Speaking Class. Journal of English Education and Teaching (JEET). 3(3), 343-360.

Park, Hyesook \& Lee, Adam. R. (2005). L2 Learners' Anxiety, Self-confidence and Oral Performances. Kunsan National University, Concordia University

Payne, J., Huddleston, R., \& Pullum, G.K. (2010). The Distribution and Category Status of Adjectives and Adverbs. Word Structure. 3(1), 31-81.

Pratama, N. H., Laksmi, E. D., \& Irawati, E. (2018). How Much Do the Affective Factors.

Putrawansyah, A. (2020). Effectiveness Of Using Youtube Video In Improving Students' Speaking Skill Through Asking And Answer Questions.

Rababah, Luqman. (2020). Jadara University Students'Attitudes towards the Use of Microsoft Teams in Learning English as a Foreign Language. Studies in Linguistics and Literature. 4(4): 59-64.

Rahandi, A. (2020). The Effect Of Using Podcast In Students' Speaking Skill At The Second Grade Of Nursing In Baiturrahim Vocational School Jambi.

Rahmawati, F., Said, I., \& Misbahudin, M. (2020). Technology, Entertainment, Design (TED) Talk in Teaching Vocabulary. JALL: Journal of Applied Linguistics and Literacy. 4(2)

Rehouma, M. (2019). Use of Podcasts to Enhance Algerian Students' Speaking Skill: The Case of Third Year License Students of English at Hamma Lakhdar University of Eloued.

Ridho, R. A. (2020). Exploring EFL Students' Perception of Online Learning via Microsoft Teams : University Level in Indonesia. English Language Teaching Educational Journal. 3(2) : 163-173.

Risky, A.S. (2016). Students' Perception on The video Project in Their Speaking Class : A Study of 11th Grade of SMAN 1 Kasihan Students.

Sanga, L. (2021). Microsoft Teams 365 and Online Learning: The Students Perception. Jurnal Pendidikan Kimia. 13(2): 131-136.

Sayuri. (2016). Problems in Speaking Faced by EFL students of Mulawarman University. Indonesian Journalof EFL and Linguistics. 1(1)

Septiani, R. (2014). The Correlation Between Grammar Mastery and Writing Ability.

Sikder, S. (2016). Role Of A Teacher In Teaching Speaking By Following A Communicative Approach: To What Extent Is This Possible In An Esl Context Like Bangladesh?. Global Journal Of HumanSocial Science: G Linguistics \& Education. 16(3).

Tahani, R.K \& Behak, F. (2021). The Impact Of Microsoft Teams App in Enhancing Teaching-Learning English During Covid-19 From English Teachers Perspective in Jenin City. MJoSHT : Malaysian Journal Of Science, Health and Technology. 7(1) : 102 - 109.

Thornbury, S. (2005). How to Teach Speaking. New York : Pearson Education Limited.

Vauhkonen, O. (2020). Implementation Of Microsoft Teams at organizations in Finland.

Wahyu, F. (2020). The Students' Speaking Accuracy And Fluency Ability In Video Production Through Online Learning Process.

Wang, Zhiqin. (2014). Developing Accuracy and Fluency in Spoken English of Chinese EFL Learners. English Language Teaching. 7(2) : 110-118.

Widiyarso, T. H \& Sutama, S. (2021). Efektifitas Penggunaan Micrososft Teams dalam pembelajaran E-Learning Bagi Guru Selama Pandemi Covid-19. Didaktis : Jurnal Pendidikan dan Ilmu Pengetahuan. 21(1).

Wulandari, Rian. (2014). Improving Students' Speaking Ability Through Communicative Language Games at Smpn 1 Prambanan Grade VIIIA in The Academic Year Of 2013 / 2014. 
UMGCINMATIC : $1^{\text {st }}$ Rethinking Education during Covid-19 Era: Challange and Innovation Volume 1 No 2

Yen, T. V. M \& Nhi, T. (2021). The Practice of Online English Teaching Learning with Microsoft Teams : From Students' View. AsiaCALL Online Journal. 12 (2) : 51-57.

Zermeño, D. A. G. (2015). A case study of negative affective factors among EFL students performing below expectations in the city of Monterrey, Mexico. 